\title{
KEBEBASAN PERS DAN HAK PUBLIK
}

\author{
Acan Mahdi
}

\begin{abstract}
Abstrak
Tulisan ini adalah upaya melihat kembali urgensi kebebasan pers bagi masyarakat. Dengan mere-vew ulang konsep kebebasan pers, dan melihat praktik kebebasan pers dibeberapa negara, tulisan ini mengantarkan kita pada kesimpulan bahwa, kebebasan pers merupakan hak asasi warga Negara. Karenanya, kebebasan pers dalam masyarakat demokrasi merupakan pengejawantahan hak asasi manusia tersebut. Dengan membuka kran demokrasi melalui kebebasan pers berarti kita membuka atau memberikan kesempatan kepada warga Negara untuk mendapatkan hak asasinya. Kajian-kajian mengenai urgensi kebebasan pers bagi masyarakat menunjukkan bahwa kebebasan pers sangat membantu masyarakat dalam mendapatkan hak-hak publiknya seperti, partisipasi dalam politik, akses kesehatan dan pendidikan yang baik, serta menjaga kekuasaan dari prilaku menyimpang dan korupsi. Kebebasan pers bahkan menjadi jaminan bagi investor untuk menanamkan modalnya.
\end{abstract}

Kata Kunci: Kebebasan Pers, Hak Publik

\section{A. Muqaddimah}

Dalam pengayaannya, tulisan ini akan dimulai dengan memaparkan mengenai konsep kebebasan pers, kebebasan pers dan masyarakat, dan beberapa catatan yang penting untuk menjadi bahan diskusi. Terakhir, tulisan ini akan memperlihatkan "benang merah" dari keseluruhan isi tulisan ini, seperti pada kesimpulan.

\section{B. Konsep Kebebasan Pers}

Kebebasan pers di sini adalah sebagai terjemahan dari freedom of the press, yang dianalogikan sebagai kebebasan dari penguasa. Dalam sejarah (Adinegoro,1961: 60), pengakuan dan perlindungan atas hak untuk bebas dari pengaruh atau tekanan penguasa sudah dimulai sejak deklarasi Magna Charta (1215). Dalam konteks pers, secara eksplisit ditetapkan dalam Pasal 12 Virginia Bill of Right (15 Mei 1776) tentang kebebasan persuratkabaran. Selanjutnya, spirit Piagam Virginia dimasukkan ke dalam Konstitusi Amerika Serikat (1787). Kemudian, tahun 1789, 
Piagam Virginia diadopsi pula oleh Perancis.

Kebebasan pers dengan demikian adalah kebebasan berkomunikasi dan berekspresi dalam memberikan informasi kepada publik melalui media massa, baik media cetak maupun media elektronik. Kebebasan ini menunjuk tidak adanya campur tangan Negara atau pemerintah maupun elemen masyarakat lain, baik individu maupun kolektif dalam memberikan informasi kepada publik, dan secara konstitusional keberadaanya dilindungi oleh negara.

Salah satu pendekatan untuk melihat praktik kebebasan pers adalah dengan teori pers bebas (libertarian). Teori pers bebas (libertarian) merupakan antitesa dari pendekatan sebelumnya dalam praktik pers, yaitu pers otoriter (outritarian), yang menjadikan pers sebagai subordinat pemerintah atau negara. Sebagaimana nama yang melekat pada dirinya, pers libertarian merupakan praktik kebebasan pers, yang dalam praktiknya menolak intervensi pemerintah atau penguasa dalam memberikan informasi kepada khalayak pembacanya. Pers, dalam teori libertarian bukan subordinat dari penguasa, melainkan mitra sejajar pemerintah dalam menjalankan roda pembangunan. Penelitian ini hanya akan membahas dan menggunakan pers libertarian atau pers bebas sebagai pendekatan untuk melihat fenomena praktik kebebasan pers di tanah air.

Pers bebas diyakini lahir dari rahim libertarian, yang menjadikan kebebasan individu sebagai hak asasi. Siebert (1986: 43) menjelaskan bahwa lahirnya pers bebas dipengarui oleh filsafat libertarian yang berkembang di abad XVII dan XVIII. Prinsip-prinsip demokrasi yang menghargai dan memberikan kebebasan individu dalam memandang realitas sosial merupakan prinsip-prinsip utama dalam filsafat libertarian. Manusia menurut kaum libertarian adalah binatang yang rasional dan memiliki tujuan sendiri. Kebahagian dan kesejahteraan individual adalah tujuan masyarakat, dan manusia sebagai organisme yang berfikir, sanggup mengorganisir dunia sekelilingnya dan membuat keputusan yang dapat memajukan kepentingannya. Para filsuf libertarian menolak dengan tegas anggapan bahwa negara adalah ekpresi usaha manusia yang tertinggi, meski mereka mengakui dengan sedikit keraguan, bahwa negara merupakan alat yang berguna dan bahkan sangat diperlukan. Kebenaran menurut kaum libertarian adalah sesuatu yang bisa saja berbeda dengan yang diajarkan sebelumnya, tetapi kebenaran merupakan kesatuan yang pasti dan dapat ditemui 
serta dapat didemonstrasikan kepada semua manusia yang berfikir. Secara sederhana menurut Siebert, teori libertarian menempatkan manusia sebagai mahluk yang berakal yang mampu membedakan sendiri mana yang benar mana yang salah. Mereka tidak perlu dibimbing oleh penguasa. Kebenaran tidak lagi menjadi milik kekuasaan, tetapi menjadi salah satu hak asasi manusia, dan karenanya menjadi milik setiap individu.

Sumbangan terpenting liberalisme dalam kehidupan masyarakat, terutama hubungan pers dan penguasa adalah pernyataan pentingnya setiap orang, kepercayaan pada kemampuan berfikirnya, dan konsep hak-hak asasi, di mana kebebasan memilih agama, berbicara, dan kebebasan pers merupakan bagiannya. Siebert (1986: 48) mengutif pendapat Prof. Carl Becker yang dianggap sangat tepat sebagai landasan bagi pemikiran di atas, sebagai berikut:

"doktrin demokrasi tentang
kebebasan berbicara dan
kebebasan pers apakah itu
dianggap sebagai hak asasi atau
hak yang tidak dapat dipindahkan,
berdasarkan pada beberapa
asumsi. Salah satu di antaranya
adalah bahwa manusia ingin
mendapatkan kebenaran dan akan
cenderung ingin dibimbing
kebenaran itu. Asumsi lain adalah,
bahwa satu-satunya cara yang
pada akhirnya akan memberikan
kebenaran adalah kompetensi

opini yang bebas di "pasar terbuka". Asumsi lainnya lagi mengatakan bahwa karena setiap orang berbeda-beda pendapatnya, maka setiap orang harus diperbolehkan menyampaikan secara bebas dan bahkan giat pendapatnya sendiri, asalkan ia mengijinkan ula orang lain menggunakan hak yang sama. Asumsi terakhir mengatakan bahwa dengan adanya saling toleransi dan saling membandingkan opini-opini yang berbeda itu akan muncul opini yang terbukti paling rasional dan dapat diterima semua pihak."

\section{Abad XVIII diyakini Siebert} sebagai abad dimana prinsip-prinsip pers secara keseluruhan beralih dari otoritarisn ke libertarian. Pada awal abad tersebut, lanjut Siebert, pengawasan pers otoritarian sedang sekarat. Kekuasaan kerajaan untuk mengatur pers telah dihapuskan, gereja tidak lagi berfunsi sebagai agen-agen pengatur, dan monopoli negara dalam penerbitan telah dihapuskan. Menjelang akhir abad itu, prinsip-prinsip pers libertarian disisipkan dalam hukum dasar dan kalimat undangundang yang melindungi kebebasan berbicara dan kebebasan pers. Siebart mencatat setidaknya ada tiga orang Inggris dan satu orang Amerika yang telah memberikan sumbangansumbangan penting dalam masa transisi, yaitu: John Milton di abad XVII; John Erskine dan Thomas Jefferson pada abad XVIII; dan John Stuart Mill d abad XIX. 
Pernyataan Mill yang terkenal mengenai pentingnya kebebasan individu untuk berekspresi seperti yang dikutif Siebert berikut ini:

"Jika semua umat manusia kecuali satu orang, punya satu pendapat yang sama dan hanya satu orang pendapatnya yang berbeda, maka umat manusia tidak dibenarkan untuk membungkam yang satu orang itu, sama halnya orang yang satu itu, jika punya kekuasaan, tidak dibenarkan membungkam umat manusia. Jika sebuah opini merupakan milik perorangan yang tidak ada nilainya selain untuk dirinya sendiri; jika dihilanginya kesempatan untuk menikmati opini itu semata-mata merupakan sebuah kerugian pribadi, maka akan ada kerugian yang dibebankan pada sedikit orang atau pada banyak orang. Tetapi membungkam pernyataan pendapat merupakan kejahatan karena membungkam itu adalah perampokan terhadap manusia; anak cucu kita dan generasi yang sekarang ini; mereka yang tidak sepakat dengan opini itu, tetap lebih banyak daripada yang meyetujuinya. Jia itu benar, mereka kehilangan kesempatan untuk merubah kesalahan menjadi kebenaran; jika opini itu salah, mereka kehilangan keuntungan yang begitu besar, yaitu pemahaman yang lebih jelas dan kesan yang lebih hidup tentang kebenaran sebagai tabrakan antara kebenaran itu dengan kesalahan."

Selain itu Siebert juga mengutif pendapat Thomas Jefferson tentang kebebasan pers, filsuf dan juga seorang negarawan, seperti di bawah ini. "tidak ada eksperimen yang lebih menarik daripada eksperimen kita sekarang ini dan yang kita yakini pada akhirnya akan memberikan bahwa manusia dapat diperintah oleh pikiran dan kebenaran. Dengan demikian, obyek kita yang pertama adalah membukakan seluruh jalan bagi manusia menuju kebenaran. Cara yang terbaik yang pernah ada sampai sekarang adalah dengan kebebasan pers. Karenanya, perslah yang lebih dahulu dibungkam oleh orang-orang yang takut tindakannya diselidiki. Keteguhan rakyat dalam bertahan di tengah penyalahgunaan pers, ketajaman mereka untuk membedakan antara kebenaran dan keselahan, menunjukkan bahwa mereka dapat dipercaya untuk mendengarkan semua yang benar dan salah. Karena itu saya meyakininya, untuk lebih pasti, bahwa membuka pintu kebenaran, dan membentengi kebiasaan menguji segalanya dengan akal pikiran, adalah rantai-rantai paling tepat untuk diikatkan pada tangantangan para petugas kita, untuk mencegah agar mereka nanti tidak membelenggu rakyat dengan dasar keinginan sendiri."

Pers bebas (libertarian) pada dasarnya menunjuk dan mengindikasikan tidak adanya campur tangan penguasa (pemerintah), maupun setiap elemen masyarakat lain, baik perorangan maupun kolektif dalam menyampaikan informamsi kepada publik. Hal ini merupakan implikasi pratis dari prinsip-prinsip dasar demokrasi. Memang secara historis, pers libertarian tumbuh dan berkembang dari rahim demokrasi. 


\section{Kebebasan Pers dan Masyarakat}

Bagi masyarakat demokratis, pers bahkan dibaca sebagai pilar keempat, selain eksekutif, yudikatif dan legislatif. Pers dalam konteks ini berfungsi sebagai "anjing penggonggong", selain fungsi ekonomi, informasi, hiburan dan pendidikan bagi masyarakat. Pengawasan yang ketat oleh pers bagi kehidupan berbangsa, terutama dalam pelaksanaan pemerintahan menempatkan dirinya sebagai kekuatan lain diluar pemerintah dalam arti luas. Hal ini wajar, dari beberapa kajian literatur yang peneliti lakukan, seperti yang telah dipaparkan sebelumnya menunjukkan peranan pers yang begitu signifikan dalam pembangunan manusia dan masyarakat. Kebebasan pers, berdasarkan penelitianpenelitian tersebut berbanding lurus dengan prilaku korupsi oleh pelaksana pemerintahan. Kebebasan pers juga berdasarkan penelitian tersebut, berbanding lurus dengan kehidupan yang lebih baik, akses kesehatan dan pendidikan yang baik bagi masyarakat. Kebebasan pers, seperti ditunjukkan dari penelitian tersebut, bahkan berbanding lurus dengan pengetahuan dan partisifasi politik masyarakat.

Dalam pemerintahan demokrasi, posisi pers adalah sebagai partner pemerintah dalam menjalankan roda pemerintahan. Keberadaannya sebagai penyimbang dan sebagai wadah tempat aspirasi warga negara dapat diperbincangkan. Pers dan pemerintah saling mengisi satu sama lainnya. Hubungan yang terbangun adalah simbiosis mutualisme.

\section{Diskusi}

Rudiger (2002) meneliti hubungan kebebasan pers, modal kemanusiaan dan korupsi. Penelitian ini awalnya berjudul Press Freedom, Human Capital, And Corruption. Penelitian ini dilakukan dengan survey dibeberapa Negara Eropa dan negara berkembang di Asia.

Studi ini menyimpulkan bahwa, petama, rendahnya tingkat kebebasan pers dapat menyebabkan korupsi meningkat. Bahwa di negara-negara dengan tingkat pengawasan sipil mereka yang rendah terhadap kepentingan umum, peningkatan pendidikan (pendidikan, terutama lebih maju) mungkin tidak memiliki dampak positif yang diharapkan pada korupsi, terutama saat mereka bisa meningkatkan agen sewa mencari kapasitas. Kami memberikan bukti empiris bahwa kenaikan sekunder dan pendidikan tinggi memiliki dampak negatif terhadap korupsi di negara-negara yang kurangnya kebebasan pers. Tidak, sebaliknya, tidak 
ada efek negatif seperti dari pendidikan dasar Kami kemudian berkonsentrasi pada hubungan langsung antara kebebasan pers dan korupsi. Meskipun mudah diamati dan diakui secara luas bahwa tingginya tingkat kebebasan pers cenderung berjalan seiring dengan rendahnya tingkat korupsi (dan wakil versa), kami telah menyediakan bukti bahwa penyebab berjalan terutama dari pers kebebasan untuk korupsi, yaitu tidak adanya kebebasan pers mengarah pada korupsi meningkat. Penguatan kebebasan pers dengan demikian merupakan alat yang efisien dalam memerangi korupsi.

Kedua, hubungan antara keterbukaan perdagangan dan korupsi tidak menjadi fokus utama artikel ini, namun tampaknya layak disebutkan bahwa hasil kami berbeda secara substansial dari yang disajikan dalam literatur empiris sejauh ini. Minoritas artikel tidak menemukan korelasi kuat, tetapi mayoritas menemukan korupsi lebih rendah tingkat berjalan beriringan dengan keterbukaan lebih untuk berdagang. Anehnya, kita menemukan berlawanan kuat efek dalam dimensi waktu, yaitu negara-negara yang meningkatkan keterbukaan mereka terhadap perdagangan mengalami tingkat korupsi meningkat pada saat yang sama. Sebagai masalah ini belum menjadi fokus utama dari makalah ini kami ingin menginterpretasikan temuan ini bersama kebijaksanaan, dan terutama sebagai cara untuk menunjukkan bahwa ada kebutuhan mendesak untuk penelitian lebih mendalam. Namun, ketika kita berpikir bahwa pembukaan umum di atas sebuah ekonomi untuk perdagangan internasional berkhasiat dalam dirinya sendiri, untuk saat ini kami akan meminta untuk sangat hati-hati dalam membuka advokasi demi melawan korupsi.

T. Leeson (2005) melakukan studi dengan judul Media Freedom, Political Knowledge, and Participation. Seperti judulnya penelitian ini menitikberatkan pada relasi kebebasan media terhadap pengetahuan dan partisipasi politik masyarakat. Studi ini dilakukan dengan survei terhadap tiga belas negara di Eropa di antaranya Turki, Romania dan Bulgaria.

Penelitian ini menyimpulkan bahwa kebebasan media yang rendah sangat terkait dengan pengetahuan politik masyarakat miskin, partisipasi politik yang yang rendah dan partisipasi pemilih yang rendah. Secara khusus, di mana negara mengontrol media, warga Negara cenderung bodoh dan apatis secara politis. Pada gilirannya, warga yang bodoh dan apatis terhadap politik, tidak punya pengetahuan politik atau tidak cukup aktif untuk secara efektif memantau atau menghukum kegiatan 
politisi mementingkan diri sendiri. Keadaan sebaliknya terjadi di Negara dengan kebebasan media yang lebih tinggi.

Anne-Sophie Novel (2006) meneliti tentang Press Freedom and Poverty : An analysis of the correlations between the freedom of the press and various aspects of human security, poverty and governance. Studi dilakukan dengan survey dibeberapa Negara maju Eropa dan Asia. Negara maju di Asia yang menjadi sampel di antaranya adalah Jepang, sedangkan Negara berkembang di antaranya Malaysia dan Brunai Darussalam.

Studi ini berkesimpulan bahwa kebebasan pers berkorelasi positif terhadap tingkat pembangunan yang baik dan mengurangi kemiskinan. Studi ini juga memperlihatkan hubungan yang positif antara kebebasan pers dan akses kesehatan yang layak, dan akses pendidikan yang baik. Namun penelitian ini memberikan pengecualian, bahwa kebebasan pers bukanlah barang mewah bagi negara-negara dengan tingkat ekonomi tinggi, seperti di Jepang, Malaysia dan Brunai Darussalam. Ketiga negara ini berhasil membangun dengan baik, dengan tingkat kemiskinan yang kecil, akses kesehatan yang layak dan pendidikan yang bermutu bagi masyarakatnya, meskipun tingkat kebebasan pers yang rendah.

Pippa Norris (2006), mencoba mengukur dampak kebebasan pers terhadap berbagai indikator demokrasi. Penelitian ini berjudul The Role of the Free Press in Promoting Democratization, Good Governance, and Human Development. Penelitian ini dilakukan dengan survei diberbagai negara di empat benua, kecuali Australia. Untuk benua Asia, di antaranya China dan Iran, benua Eropa di antaranya Swedia dan Belgia, Afrika di antaranya Nigeria dan Rwanda, dan Benua Amerika di antaranya Cuba dan Venezuela. Studi ini menyimpulkan bahwa terdapat korelasi yang positif antara kebebasan pers dengan penegakan demokrasi, pemerintahan yang baik dan pembangunan manusia disebuah negara. Keseluruhan analisis memberikan dukungan yang besar terhadap klaimklaim dari teoretisi liberal tentang peran kritis pers bebas, sebagai salah satu komponen utama dari kedua demokrasi dan pemerintahan yang baik. Ini berfungsi untuk mengkonfirmasi apa yang banyak telah lama dicurigai atau dianggap tidak kritis, tetapi seperti konfirmasi penting untuk mengintegrasikan kembali studi tentang struktur komunikasi politik menjadi pendekatan standar untuk menjelaskan 
proses demokratisasi. Struktur media berita dan peran yang mengadopsi jurnalis merupakan komponen penting dari pemahaman yang lebih komprehensif perubahan rezim.

Marina Guseva, Dkk. (2007) dengan studinya berjudul Press freedom and development : An analysis of correlations between freedom of the press and the different dimensions of development, poverty, governance and peace. Studi ini dilakukan dengan survei diberbagai negara dunia. Studi menyimpulkan bahwa pertama, kebebasan pers sangat terkait dengan tingkat pembangunan dan tingkat kemiskinan di suatu negara, terpenuhinya kebutuhan, akses kesehatan dan pendidikan yang layak. Dua, bahwa kebebasan pers secara positif berkorelasi terhadap tata pemerintahan. Negaranegara yang tidak memeiliki kebebasan pers cenderung mangalami krisis pemerintahan. Individu berdasarkan penelitian ini cenderung mengabaikan sistem mereka dalam membangun sehingga menyalahgunakan kekuasaan. Tiga, kebebasan pers berkorelasi positif dengan rendahnya tingkat pengeluaran militer dan personil militer. Hubungan antara kebebasan pers dan kekerasan atau keamanan sangat lemah. Kurangnya data numerik yang dapat digunakan berarti bahwa tidak ada yang sangat kuat kesimpulan yang dapat dihubungi tentang kaitan antara kebebasan pers dan pribadi keamanan.

Nabamita Dutta-Sanjuta Roy (2007), melaukan penelitian dengan judul The Role of Foreign Direct Investment on Press Freedom. Sama dengan penelitian yang dilakukan Eun Sak SA, penelitian ini menjadikan kebebasan pers sebagai variabel yang dipengaruhi (devendent variable). Secara umum penelitian penelitian ini menyimpulkan bahwa peran investasi langsung luar negeri berkorelasi positif terhadap kebebasan pers. Dijelaskan dalam penelitian ini bahwa tingkat investasi luar negeri yang tinggi berdampak positif terhadap sektor media dan kebebasan pers.

Revianti (2006) meneliti Budaya Sensor-Diri Dalam Kebebasan Pers di Jepang. Studi dilakukan dengan pendekatan kualitatif, dengan empat teori dasar pers sebagai pisau analisis. Penelitian ini menyimpulkan bahwa, pertama, kontrol pemerintah terhadap pers Jepang tidak begitu jelas terbuka sebagaimana terjadi pada negara-negara lain, namun control oleh organisasiorganisasi media sendiri sangat efektif dan menghasilkan keadaan yang sama sebagaimana pada situasi public yang tidak mendapatkan informasi cukup tentang pelaksanaan pemerintahan. Bahwa pers Jepang acapkali dikatakan 
atau dianggap bebas, bahkan mungkin paling bebas di Asia, adalah karena pemerintah Jepang jarang mengambil tindakan pembatasan langsung secara terbuka terhadap pers.

Kedua, tindakan pembatasan langsung atau sensor terhadap pers oleh pemerintah atau kelompok yang berkuasa lain mungkin tidak perlu dilakukan, karena pers atau kalangan media Jepang sendiri telah dengan cermat, rajin dan hati-hati melakukan pengawasan terhadap dirinya sendiri. Sensor-diri telah menjadi semacam hal yang terinternalisasi dan dengan penuh kesadaran dan sukarela mereka lakukan, karena tidak mau mengganggu harmoni yang sudah terjalin antara media, pemerintah dan korporasi.

Tiga, Bahwa, dalam masa transformasi sosial di Jepang, media turut memainkan peranannya sebagai sarana informasi, edukasi, dan entertainment. Namun keadaan budaya masyarakat Jepang yang lebih mementingkan hubungan harmonis dari pada kebebasan pers dan kebebasan menyatakan pendapat, system politiknya serta perkembangan sejarahnya, menjadikan lebih diutamakan praktek sensor-diri pada media jepang.

Empat, keunikan keadaan pers yang terkait dengan nilai budaya di Jepang ini - dan mungkin juga hal yang sama terdapat di Negara-negara Asia lain dengan kekhasan konteks budayanya masing-masing menjadikan teori-teori pers dasar tidak dapat sepenuhnya diterapkan di Jepang.

Mark Pearson dan Camille Galvin (2007) meneliti peran Parlemen Australia dalam menyuarakan kebebasan dalam konteks internasional. Penelitian berjudul The Australian parliament and press freedom in an internasional context. Studi dilakukan dengan pendekatan kualitatif dengan grouded Glaser dan Strauss theori untuk menjawab pertanyaan penelitian. Penelitian ini berkesimpulan bahwa, pertama, jumlah dan berbagai negara yang disebutkan oleh anggota parlemen dalam konteks kebebasan pers menunjukkan bahwa mereka melihat kebebasan pers sebagai isu internasional dan bahwa Australia memiliki hak untuk mengucapkan atas dengan kewenangan tertentu, meskipun tidak tampaknya otoritas sebanyak Amandemen Pertama Amerika Serikat yang masih dianggap sebagai benchmark kebebasan pers. Ada alasan lagi bahwa diskusi pers kebebasan dipertimbangkan dalam konteks internasional, karena komunikasi dengan teknologi modern termasuk Internet dan isu-isu keamanan internasional telah membuat diskusi tentang kebebasan pers dalam konteks murni dalam negeri kurang relevan. anggota parlemen Australia senang untuk 
menyajikan kebebasan pers Australia sebagai sebuah mercusuar ke negaranegara kurang demokratis. Namun, ini mungkin sedikit lancang sejak hanya peringkat 41 dalam Reporters Without Borders (RSF) indeks tahunan kebebasan pers (Pacific Media Watch, 2004). Australia menempati peringkat di belakang beberapa mantan Blok timur negara dalam indeks, termasuk Hungaria (28), Republik Ceko (19) dan Polandia (32), antara kritik dari pengawas yang tentang kebijakan-kebijakan yang membatasi tekan akses ke pengungsi.

Dua, Australia berdiri di Irak dan partisipasinya dalam Koalisi dan bersedia dalam Perang Irak pada tahun 2003 bisa ditafsirkan oleh beberapa orang sebagai makna yang memperjuangkan nilai-nilai dasar demokrasi seperti kebebasan pers yang telah mengambil langkah melampaui retorika.

Dubrovnik (2007) mencoba mempertanyakan masa depan kebebasan pers dan demokrasi di negaranya. Penelitian ini berjudul The Future of Press Freedom and Demokrasy in Croatia. Penelitian ini dilakukan dengan pendekatan kualitatif, dengan empat teori dasar pers sebagai pisau analisis. Penelitian ini menyimpulkan bahwa, pertama, pengaruh politik yang kuat terhadap wartawan yang diizinkan untuk secara bebas memberikan informasi kepada masyarakat tentang informasi yang tidak relevan, namun masalah politik yang halus masih di bawah kontrol pemerintah.

Kedua, Kroasia dapat meningkatkan kebebasan pers untuk menciptakan masyarakat yang lebih demokratis dengan memperhatikan pentingnya pendidikan publik dan wartawan yang tidak boleh jatuh di bawah pengaruh politik manipulator, tetapi menggunakan penilaian akal mereka sendiri sebagai gantinya.

Raymond Louw (2008) meneliti tentang kebebasan media, transparansi dan pemerintahan. Judul asli penelitian ini adalah Media Freedom, Transparency and Governance. Studi ini dilakukan diempat Negara benua Afrika, yaitu Ghana, Kenya, Rwanda dan Afrika Selatan. Penelitian ini berkesimpulan bahwa kasus di empat negara ini Ghana, Kenya, Rwanda dan Afrika Selatan - memperlihatkan kebebasan ekspresi yang tertutup dalam laporan mereka ke Uni Afrika. Di Kenya, misalnya, pers itu dianggap penting, whistle blower untuk prilaku korupsi; di Rwanda, masalah ini rumit dengan peran yang dimainkan oleh beberapa wartawan - dan lain-lain yang menyamar sebagai wartawan - selama genosida 1994. 


\section{E. Kesimpulan}

Pembahasan di atas mengantar kita pada kesimpulan bahwa, kebebasan pers merupakan hak asasi warga Negara. Karenanya, kebebasan pers dalam masyarakat demokrasi merupakan pengejawantahan hak asasi manusia tersebut. Dengan membuka kran demokrasi melalui kebebasan pers berarti kita membuka atau memberikan kesempatan kepada warga Negara untuk mendapatkan hak asasinya.

Kajian-kajian mengenai urgensi kebebasan pers bagi masyarakat menunjukkan bahwa kebebasan pers sangat membantu masyarakat dalam mendapatkan hak-hak publiknya seperti, partisipasi dalam politik, akses kesehatan dan pendidikan yang baik, serta menjaga kekuasaan dari prilaku menyimpang dan korupsi. Kebebasan pers bahkan menjadi jaminan bagi investor untuk menanamkan modalnya. Meskipun kajian-kajian ini bersifat kuantitatif, tetapi paling tidak membuka mata kita bahwa kebebasan pers sedikit banyak membantu dalam mewujudkan masyarakat yang lebih baik. Namun harus dicatat juga bahwa dalam konteks tertentu, kebebasan pers bukanlah "barang" mahal. Studi-studi kuantitatif di atas memberikan gambaran kepada kita bahwa terdapat Negaranegara terutama di Asia, yang tidak memiliki kebebasan pers, namun mampu memberikan hak public kepada msayarakatnya dengan baik.

\section{F. Daftar Bacaan}

Buku

D. Adinegoro, 1961. Publistik dan Djurnalistik, cet. 1 Jakarta: Gunung Agung

Siebert, F.S., Theodore Peterson, dan Wilbur Schramm. 1956. Four Theories of the Press. Urbana, IL: University of Illinois Press.

Internet

Anne-Shove Novel, 2006. Press Freedom and Poverty : An analysis of the correlations between the freedom of the press and various aspects of human security, poverty and governance, (Jurnal Penelitian), http://portal.unesco.org/ (11/04/2010);

Dubrovnik, 2007. The Future of Press Freedom and Democracy in Croatia, (Jurnal penelitian), http://www.cpi.hr/ download/links/hr/8277.pdf (26/5/2010)

Eun Suk SA, 2006. Factor influencing freedom of the press in South Korea: A survey of Print 
Journalists opinions, (Jurnal

Penelitian),

http://www.ccsenet.org/journal/in

dex.php/ass/article/view/202/291

0 (3/05/2010);

Ilya Revianti Sudjono, 2006. Budaya

Sensor-Diri dalam Kebebasan

Pers di Jepang, (Jurnal

penelitian), http://journal.ui.ac.id/

Marina Guseva dkk, 2007. Press

Freedom and Development: An

Analysis of Correlations between

freedom of the Press and the

different dimentions of

development, poverty

government and peace, (Jurnal

penelitian),

http://unesdoc.unesco.org/

images/

0016/001618/

161825e.pdf

Mark Pearson dan Camille Galvin, 2007, The Australian parliament and press freedom in an internasional context, (Jurnal penelitian),

http://epublications.bond.edu.au/

cgi/

viewcontent.cgi?article $=1256 \&$ co

ntext=hss_pubs $(3 / 05 / 2010)$

Nabamita Dutta and Sanjukta Roy, 2007. The Role of Foreign Direct Investment on Press Freedom, (Jurnal Penelitian),

http://mpra.ub.uni-
muenchen.de/10185/1/The_Role _of_Foreign_Direct_Investment_ on_Press_Freedom.pdf, (25/06/2010);

Rudiger Ahrend, 2002. Press Freedom, Human Capital, and Corruption. (Jurnal Penelitian), http://www.delta.ens.fr/ abstracts/wp200211.pdf

Raymond Louw, 2008. Media Freedom, Transparency and Governance, (Jurnal Penelitian), http://www.afrimap.org/ english/images/documents/SAIIA _Louw_Media_200809.pdf, (26/06/2P010)

Peter T. Leeson, 2005. Media Freedom, Political Knowledge, and Participation, (Jurnal Penelitian), http://www. peterleeson.com /ig_and_ap.pdf (6/7/10);

Pippa Norris, 2006. The role of the free press in promoting democratization, good governance, and human development, (Jurnal Penelitian) //www. humanrightsinitiative.org/ programs/ai/rti/articles/ undp_rti_2006/annex3_backgrou nd_paper.pdf, (12/04/2010); 